\begin{tabular}{|l|l|l||}
\hline \multicolumn{2}{|c|}{ PublisherInfo } \\
\hline \hline PublisherName & $:$ & BioMed Central \\
\hline \hline PublisherLocation & $:$ & London \\
\hline \hline PublisherImprintName & $:$ & BioMed Central \\
\hline \hline
\end{tabular}

\title{
2003 Gairdner International Awards announced
}

\begin{tabular}{|l|l|l||}
\hline \multicolumn{2}{|c|}{ ArticleInfo } \\
\hline \hline ArticleID & $:$ & 4748 \\
\hline \hline ArticleDOI & $:$ & $10.1186 /$ gb-spotlight-20030411-02 \\
\hline \hline ArticleCitationID & $:$ & spotlight-20030411-02 \\
\hline \hline ArticleSequenceNumber & $:$ & 100 \\
\hline \hline ArticleCategory & $:$ & Research news \\
\hline \hline ArticleFirstPage & $:$ & 1 \\
\hline \hline ArticleLastPage & $:$ & 2 \\
\hline \hline & & RegistrationDate : 2003-4-11 \\
\hline ArticleHistory & $:$ & OnlineDate \\
\hline \hline ArticleCopyright & $:$ & BioMed Central Ltd2003-11 \\
\hline \hline ArticleGrants & $:$ & \\
\hline \hline ArticleContext & $:$ & 130594411 \\
\hline \hline
\end{tabular}




\section{David Bruce}

Email: davidb@biomedcentral.com

Five researchers have been honored in the 2003 International Gairdner Awards (sponsored by the Canadian Institutes of Health Research) announced April 8. The citation recognizes that the winners "have done elegant, provocative and essential work in neuroscience and immunology."

Richard Axel and Linda B. Buck are commended for their work exploring the neurological basis of our perception of the sensory environment "through brilliant technical innovation and creative analysis of neural circuits". The committee also recognized Seiji Ogawa for his use of functional magnetic resonance imaging (fMRI) in the non-invasive imaging of the brain that represents a "technological revolution in neuroscience and is being explored in such clinical domains as ageing and pre-surgical mapping."

The structural biologist Wayne A. Hendrickson pioneered a novel x-ray diffraction technique that identified CD4, a key molecule in the binding of HIV to their target cells. Ralph M. Steinman discovered dendritic cells - the immune cells that control the process of differentiating between self and non-self. They are both recognized for the insights they have given into fundamental immune responses.

The Foundation, established in 1957 by Toronto businessman James Gairdner, first recognized achievement in medical science in 1959. The awards are now among the most prestigious international awards in medical research. Each winner receives $\$ 30,000 \mathrm{Cdn}$. Of the past 264 awardees 59 have gone on to win a Nobel Prize.

\section{References}

1. The Gairdner Foundation, [http://www.gairdner.org]

2. Canadian Institutes of Health Research, [http://www.cihr-irsc.gc.ca/]

3. Richard Axel, [http://www.hhmi.org/research/investigators/axel.html]

4. Linda B Buck, [http://www.hhmi.org/research/investigators/buck.html]

5. Wayne A. Hendrickson, [http://www.hhmi.org/research/investigators/hendrickson.html]

6. Ralph M Steinman, [http://www.rockefeller.edu/labheads/steinman/steinman.html]

7. Nobel Prize, [http://www.nobel.se/nobel/index.html] 